\title{
Role of cyst germination in the bloom initiation of Alexandrium tamarense (Dinophyceae) in Masan Bay, Korea
}

\author{
Young-Ok Kim ${ }^{1}$, Myung-Hwan Park ${ }^{2}$, Myung-Soo Han ${ }^{1,2, *}$ \\ ${ }^{1}$ Department of Life Science, and ${ }^{2}$ Department of Environmental Science, Hanyang University, Seoul 133-791, South Korea
}

\begin{abstract}
The role of cyst germination in the bloom initiation of the toxic dinoflagellate Alexandrium tamarense was examined in Masan Bay, Korea. Germination success was measured by the incubation of cysts isolated monthly from natural sediments and compared with vegetative cells and environmental factors (temperature, salinity and dissolved oxygen) in the water column. Germination maxima (80 to $90 \%$ ) were observed during the period of decreasing water temperature in December 1996 and November 1997, while little or no germination occurred in summer. The seasonal germination exhibited an opposing pattern with temperature and similar seasonalities with salinity and dissolved oxygen, respectively. The bimodal nature of $A$. tamarense blooms, a large bloom in spring and a much smaller bloom in fall, was observed. Excysted cells in early spring can initiate the spring bloom and then proliferate to the bloom peak in increasing temperatures. Massive germination in fall contributes directly to the small bloom in fall. A temporal discrepancy between the peak of germination success and of vegetative population was found in A. tamarense dynamics from Korean coastal waters.
\end{abstract}

KEY WORDS: Alexandrium tamarense $\cdot$ Cyst germination $\cdot$ Vegetative population Resale or republication not permitted without written consent of the publisher

\section{INTRODUCTION}

Phytoplankton species can be present in high numbers for a short period in polar, boreal and temperate latitudes, where seasonal variations in environmental conditions are large (Blomquist et al. 1995). Dinoflagellate blooms are particularly important due to their deleterious effect on fishing industries and public health. Blooms of Alexandrium tamarense, a toxic dinoflagellate known to produce paralytic shellfish poison (PSP), occur regularly in many temperate coastal waters throughout the world (Therriault et. al. 1985, Méndez et al. 1996, Sekiguchi et al. 1996). Outbreaks of PSP and A. tamarense blooms along Masan Bay, a major portion of the southeastern coast of Korea, have been nearly annual events for many years (Han et

*Corresponding author. E-mail: hanms@hanyang.ac.kr al. 1992, 1993, Kim et al. 1996). However, the influence of environmental factors, including physical and chemical parameters, on the bloom of A. tamarense is not fully understood.

Life cycles, especially the resting stage, need to be taken into consideration to fully explain seasonal succession of dinoflagellate blooms. The ecology of dinoflagellate cysts, especially Alexandrium tamarense, has been studied extensively in marine environments. Blooms are initiated by the germination of benthic cysts during spring warming (Anderson \& Wall 1978, Anderson \& Morel 1979).

However, there exist different patterns of bloom initiation of dinoflagellates. A temporal discrepancy between the peak of vegetative cells and of cyst germination rates was demonstrated in Scrippsiella trochoidea and other dinoflagellate species in Japan (Ishikawa \& Taniguchi 1996, 1997). An inverse relationship between the germination ratio and the abun- 
dance of vegetative cells was found in Korean coastal waters (Kim \& Han 2000). The germination strategy of $S$. trochoidea thus showed a similar pattern in different geographical regions.

The present study examines the factors that could potentially control cyst germination and affect bloom initiation of Alexandrium tamarense. Germination success and patterns were investigated by culturing naturally occurring cysts. The seasonal relationships between germination and blooms of Alexandrium tamarense were clarified in this study.

\section{MATERIALS AND METHODS}

Study area. The sampling station was located in Masan Bay on the southeastern coast of Korea (Fig. 1) that is heavily eutrophicated because of river runoff, which includes domestic and industrial wastewaters. Masan Bay has been known to be an area that commonly has spring blooms of Alexandrium tamarense. Average water depth at the station is $12 \mathrm{~m}$.

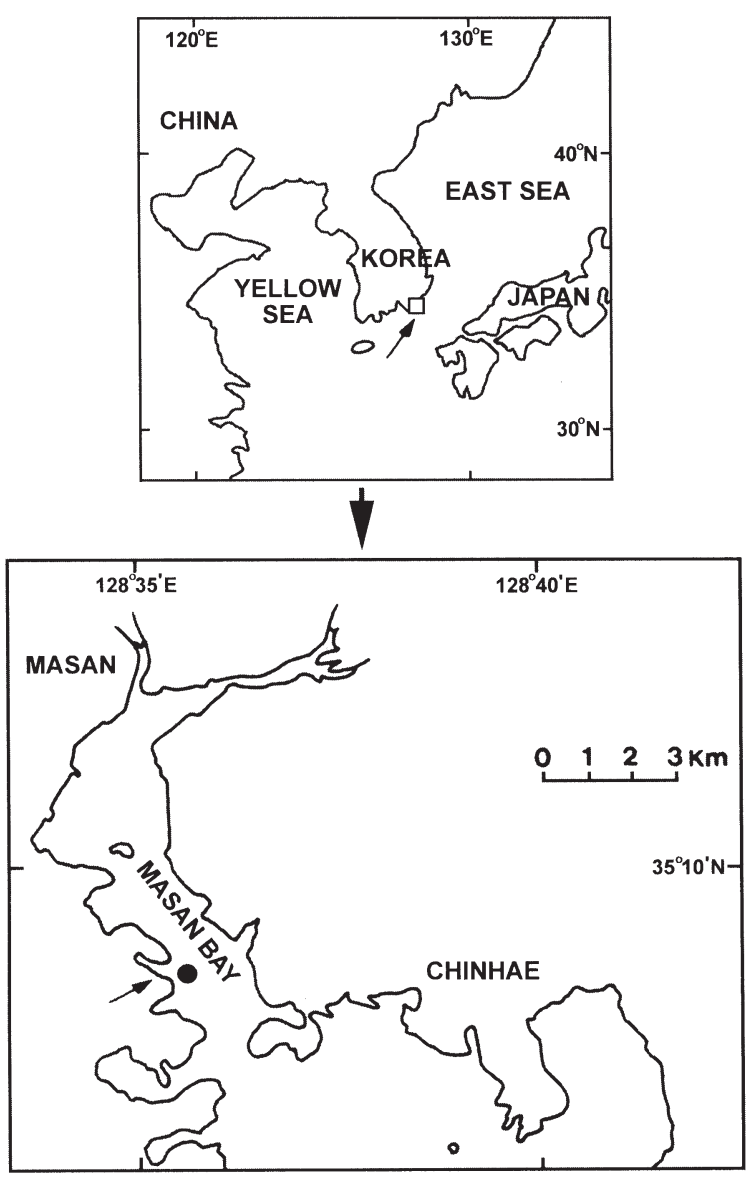

Fig. 1. Sampling site in Masan Bay on the southeastern coast of Korea
Water sampling and processing. Water samples were taken monthly from November 1996 to December 1997. A Van Dorn bottle (5 l) was utilized to collect water at $2 \mathrm{~m}$ intervals from 0 to $12 \mathrm{~m}$ depths. Subsamples were fixed in $2 \%$ (v/v) glutaraldehyde. Depending on the density of cells, 20 to $100 \mathrm{ml}$ aliquot of the fixed samples were concentrated by sieving through $20 \mu \mathrm{m}$ mesh. The vegetative cells were enumerated under a differential interference microscope (Zeiss, Axioplan) using a Sedgwick-Rafter chamber. Identification of Alexandrium tamarense was confirmed by dissecting thecal plates in $5 \%$ sodium hypochloride solution. Water temperature and salinity were recorded with a digital bathythermograph. Dissolved oxygen was measured by the Winkler method (Parsons et al. 1984).

Sediment sampling and processing. Sediment samples were collected monthly using a hand corer at the same time as the water samples. The top $2 \mathrm{~cm}$ of 3 cores were transferred to a plastic vessel and stored in the dark at $5^{\circ} \mathrm{C}$ until the cyst isolation. Surface seawater collected during each sampling time was filtered on Whatman GF/F filters, and used during the cyst isolation and culturing. The sediment in the vessel was mixed and $1 \mathrm{~g}$ wet weight was transferred into cooled, filtered seawater. This cyst suspension was sonicated for $30 \mathrm{~s}$ (Sharp UT 53N) to separate cysts from sediment, and sieved through 100 and then $20 \mu \mathrm{m}$ mesh. The 20 to $100 \mu \mathrm{m}$ fraction was transferred into filtered seawater and concentrated to a final sample volume of $10 \mathrm{ml}$. The cyst isolation and counting were done simultaneously. One $\mathrm{ml}$ of the fraction was placed in a Sedgwick-Rafter chamber and then intact cysts were counted and isolated by micropipetting using a capillary pipette under an inverted microscope. Only intact cysts with full cytoplasm and a red body were isolated and counted.

Cyst germination experiments. The isolated cysts were quickly washed in cooled, sterile filtered seawater and inoculated one by one into wells of tissue culture plates filled with the same filtered seawater. After which, they were placed on a coolant bag during the sorting. This preparation was completed within a week after sediment sampling. The isolated cysts were incubated at the water temperature measured at $12 \mathrm{~m}$ depth at the sampling station (Fig. 2A) and at $20 \mu \mathrm{mol}$ photons $\mathrm{m}^{-2} \mathrm{~s}^{-1}$ cool-white illumination with a 12:12 h light:dark cycle. For 10 d, germination of cysts was confirmed daily under an inverted microscope. Cysts that had not germinated were checked at 2 to $5 \mathrm{~d}$ intervals. The germination success was calculated as a ratio of cumulative excystment over $30 \mathrm{~d}$ compared to the total number of inoculated cysts. Each experiment with 20 cysts was performed in triplicate. 
To distinguish Alexandrium tamarense from A. catenella cysts based on morphological features is impossible. However, since $A$. catenella was not detected at the sampling site, it is assumed that all cysts examined can be described as A. tamarense.
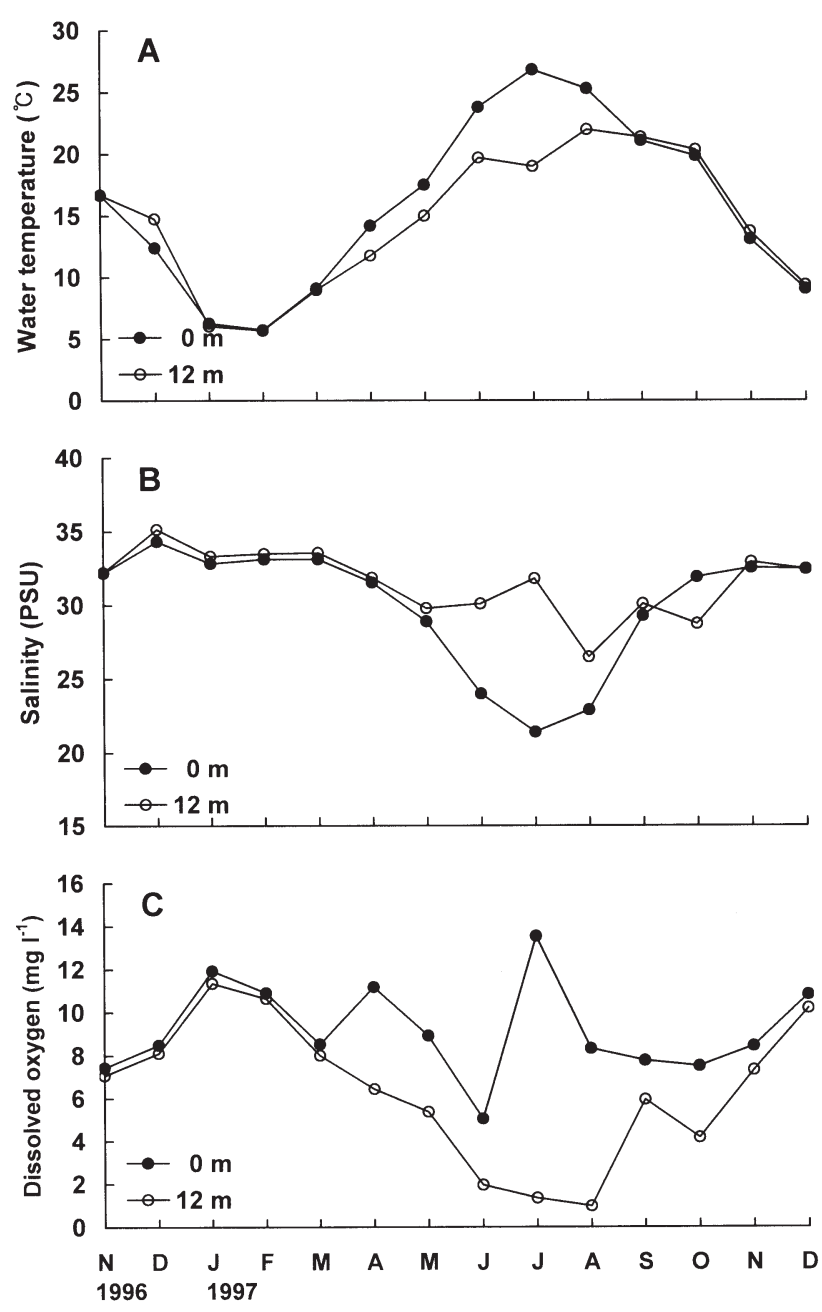

Fig. 2. Seasonal changes of (A) water temperature $\left({ }^{\circ} \mathrm{C}\right)$, (B) salinity (PSU) and (C) dissolved oxygen $\left(\mathrm{mg} \mathrm{l}^{-1}\right)$ at $0(\bullet)$ and $12 \mathrm{~m}(\mathrm{O})$ depth

\section{RESULTS}

\section{Environmental conditions}

Water temperature at the surface and $12 \mathrm{~m}$ depth displayed a clear seasonal cycle. Temperatures $<10^{\circ} \mathrm{C}$ were recorded from January to March and $>20^{\circ} \mathrm{C}$ from June to October (Fig. 2A). The seasonal maximum in August was $25.3^{\circ} \mathrm{C}$ at the surface, with a minimum of $6.0^{\circ} \mathrm{C}$ in January at $12 \mathrm{~m}$. Moderate temperatures around $15^{\circ} \mathrm{C}$ were recorded in November and December in fall, and April and May in spring.

Inverse relationships were observed between salinity and temperature. Salinity varied between 22.9 PSU in August 1997 at the surface and 35.1 PSU in December 1996 at $12 \mathrm{~m}$. Lower salinities at the surface from June to August were due to the summer monsoon (Fig. 2B).

Concentration of dissolved oxygen in the bottom layer (ca. $12 \mathrm{~m}$ ) varied seasonally as an inverse of the temperature. The concentration was greater than $8 \mathrm{mg}$ $\mathrm{l}^{-1}$ during the cold season from December to March, and as low as 1 to $2 \mathrm{mg} \mathrm{l}^{-1}$ during the warm season from June to August (Fig. 2C).

Generally, surface water conditions followed similar trends as bottom waters.

\section{Seasonal changes in vegetative cells and cysts}

The vegetative population of Alexandrium tamarense in the water column showed a typical spring bloom. Cells were detected from March coincident with an abrupt increase (from 5.7 to $9.1^{\circ} \mathrm{C}$ ) of surface temperature (Figs. 2A \& 3). Cell density reached a maximum $\left(1.0 \times 10^{4}\right.$ cells $\mathrm{l}^{-1}$ at $\left.4 \mathrm{~m}\right)$ in May when a moderate temperature $\left(17.5^{\circ} \mathrm{C}\right)$ was recorded. The cell density rapidly decreased from June when the water temperature was over $20^{\circ} \mathrm{C}$ and was followed by a summer interval with no vegetaive cells. A small population of $A$. tamarense also occurred in very low

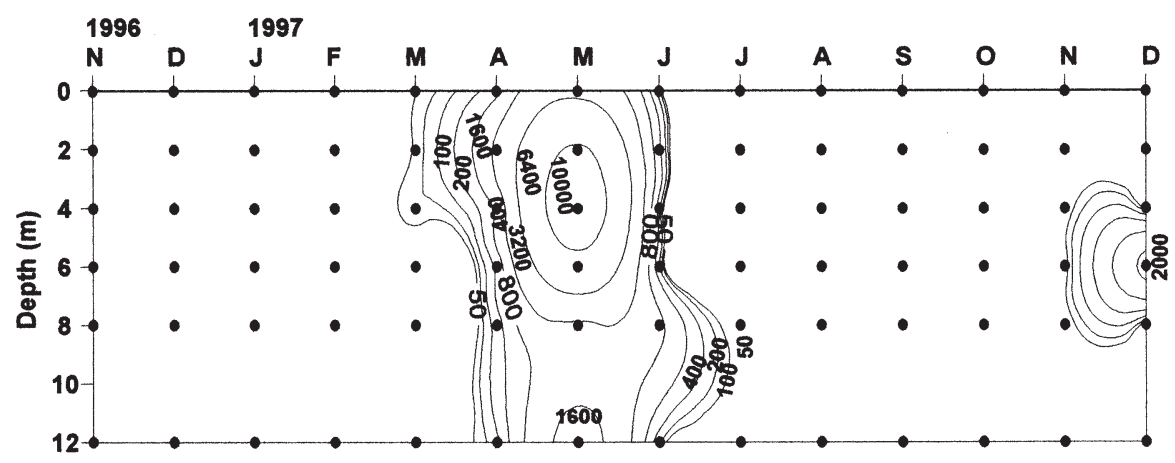

Fig. 3. Alexandrium tamarense. Seasonal changes in vertical distribution of vegetative cells (cell $\mathrm{l}^{-1}$ ) 


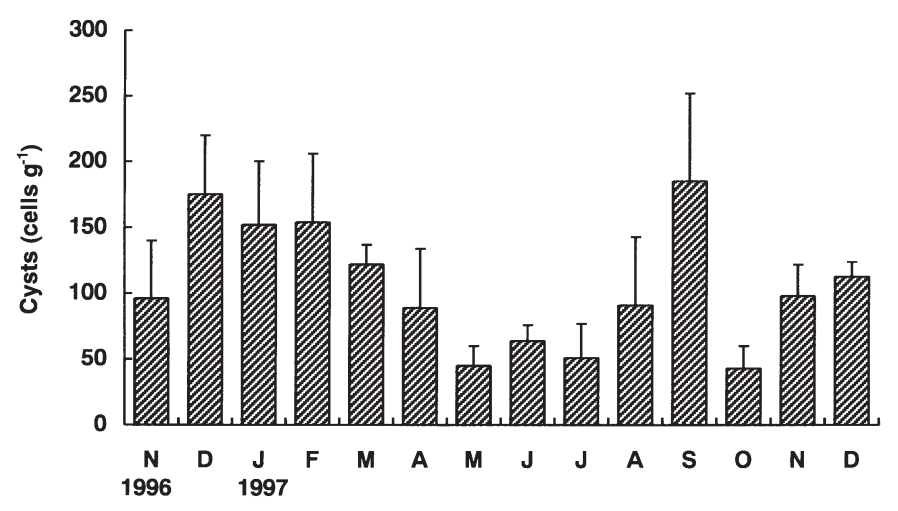

Fig. 4. Alexandrium tamarense. Seasonal changes in cyst abundance (cells ${ }^{-1}$ ) in sediment. Mean $\pm \mathrm{SD}, \mathrm{n}=3$

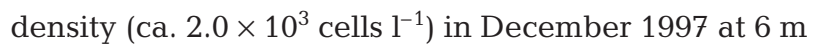
(Fig. 3). Therefore, the bimodal nature of Alexandrium blooms, a large bloom in spring and a much smaller bloom in fall, was observed in this study.

Mean cyst abundance varied from 43 to 185 cells g ${ }^{-1}$ (Fig. 4). Higher abundance above 150 cells $\mathrm{g}^{-1}$ was observed from December 1996 to February 1997. A decrease in cyst abundance beginning in March was found and this decreasing trend continued through the early summer until July. After July, a notable increase of cyst abundance was recorded until September.

\section{Seasonal change in germination ratios}

The monthly incubations of cysts demonstrate seasonally differing germination success. Germination abruptly increased within 1 or $2 \mathrm{~d}$ in November and December 1996, and reached a maximum ratio of over $70 \%$ in December 1996 (Fig. 5). From January to April, germination was delayed and gradually decreased. From May to September, germination success was significantly lower (0 to $5 \%$ ). Namely, during the warmer season the cysts showed little or no germination. A slight recovery of germination occurred in October in connection with an abrupt increase in ratio over $70 \%$ in November 1997. Therefore, germination ability displayed a similar trend in the fall of 1996 and 1997.

\section{DISCUSSION}

Among the environmental factors investigated, temperature has been shown to be most important in regulating germination of Alexandrium tamarense (Anderson \& Morel 1979, Anderson 1980). For $A$. tamarense from Cape Cod, cysts cannot germinate at cold and warm extremes. The permissive temperature window for germination ranged from 5 to $21^{\circ} \mathrm{C}$ (Ander- son 1998). Since bottom temperatures varied from 6 to $22^{\circ} \mathrm{C}$ in Masan Bay, germination might be possible throughout the year except in summer when temperatures are above $21^{\circ} \mathrm{C}$. Temperature effect was assessed by culturing naturally occurring cysts which resulted in higher germination at 10 and $15^{\circ} \mathrm{C}$, while no germination was observed at 20 and $25^{\circ} \mathrm{C}$ (Park 1999). A constant germination rate of about $20 \%$ was observed throughout the year in St. Lawrence estuary, Canada, where bottom temperature was in the range of 2 to $15^{\circ} \mathrm{C}$ (Perez et. al. 1998). Therefore, low to intermediate temperatures $\left(5\right.$ to $15^{\circ} \mathrm{C}$ ) are favorable for active germination of Alexandrium tamarense. The germination of A. tamarense in Masan Bay is more successful in winter than in summer (Fig. 6). Very little germination in summer may be a result of the inhibition of germination by the high temperatures as well as the maturation time required for newly deposited cysts.

The dormancy period of Alexandrium tamarense cysts was $2 \mathrm{mo}$ at $17^{\circ} \mathrm{C}$ (Turpin 1978), $1 \mathrm{mo}$ at $22^{\circ} \mathrm{C}$ and $4 \mathrm{mo}$ at $5^{\circ} \mathrm{C}$ (Anderson 1980). Thus, different cyst dormancy periods of the same species can be controlled by different geographic environmental conditions (Hallegraeff et al. 1998). Here, the dormancy period for Korean strains of $A$. tamarense can not be compared because of the absence of germination experiments of new cysts obtained from synchronized encystments. However, the period can be indirectly estimated by the 2 events of mass encystment in June (unpubl. data) and rapid recovery of excystment in November. The 5 mo between June and November when little or no germination has been recorded, may reflect the length of time required to achieve germination of newly formed cysts.

Oxygen is known to be another factor affecting germination by resting stages. Excystment of Alexandrium tamarense and other marine species was completely inhibited by anoxia (Anderson et al. 1987). Cysts cannot be germinated in anoxic sediments even when favorable temperature conditions are provided. Seasonal changes of excystment and bottom dissolved oxygen exhibited a similar curve (Fig. 7). Thus, the germination in the field might be inhibited by low dissolved oxygen as well as high temperatures that resulted in summer inactivity in Masan Bay.

Germination of Alexandrium tamarense cysts from natural sediments in Masan Bay was also examined under several salinity conditions, namely 25 to $34 \mathrm{PSU}$, which is within the range recorded from bottom water (Park 1999). There was no significant difference of germination success under different salinities. In the case of Alexandrium minutum in south Australia, germination success was highest between 14 to $26 \%$ (Cannon 1993). It was suggested that low salinity due to freshwater inputs increased germination of the cysts. How- 

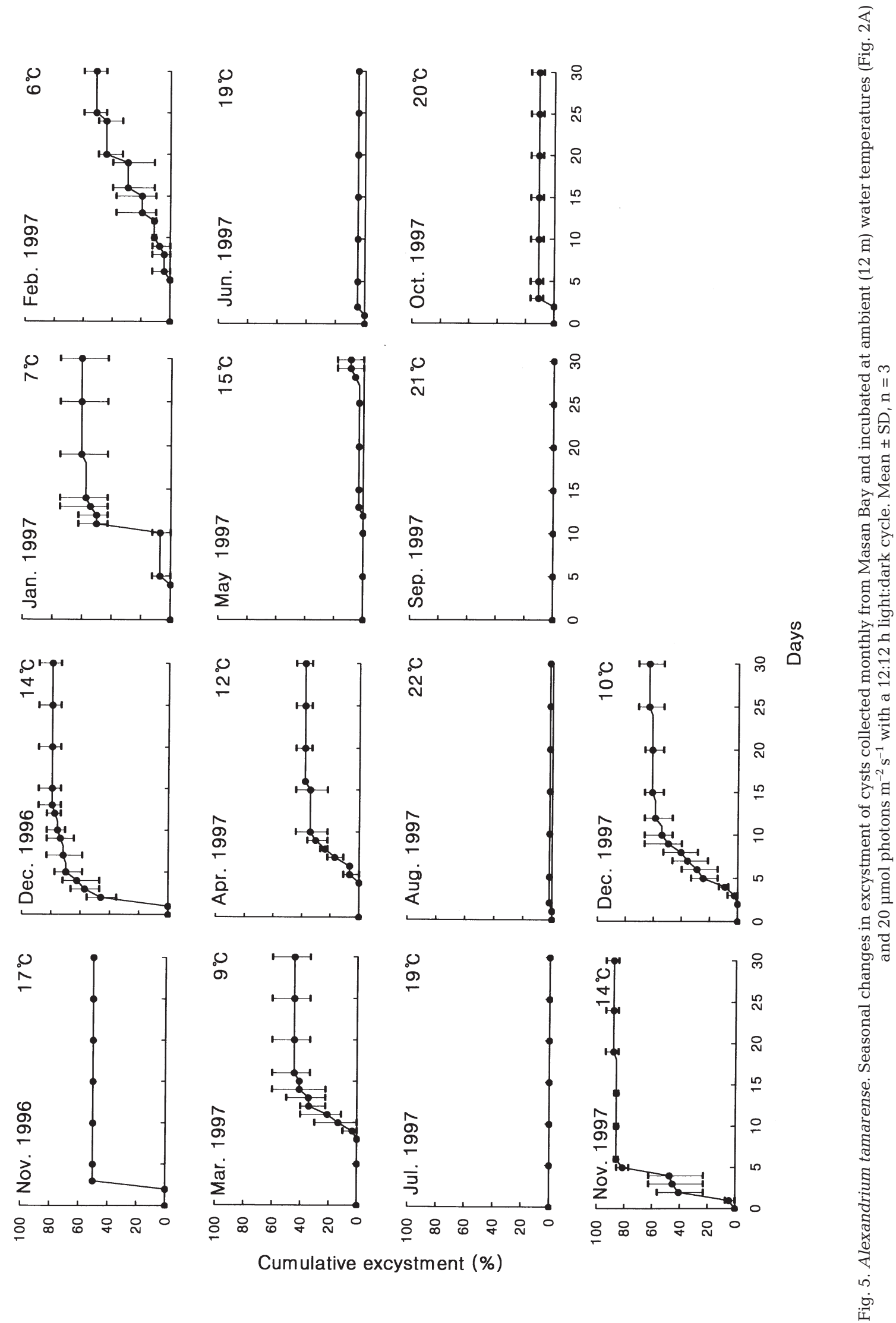


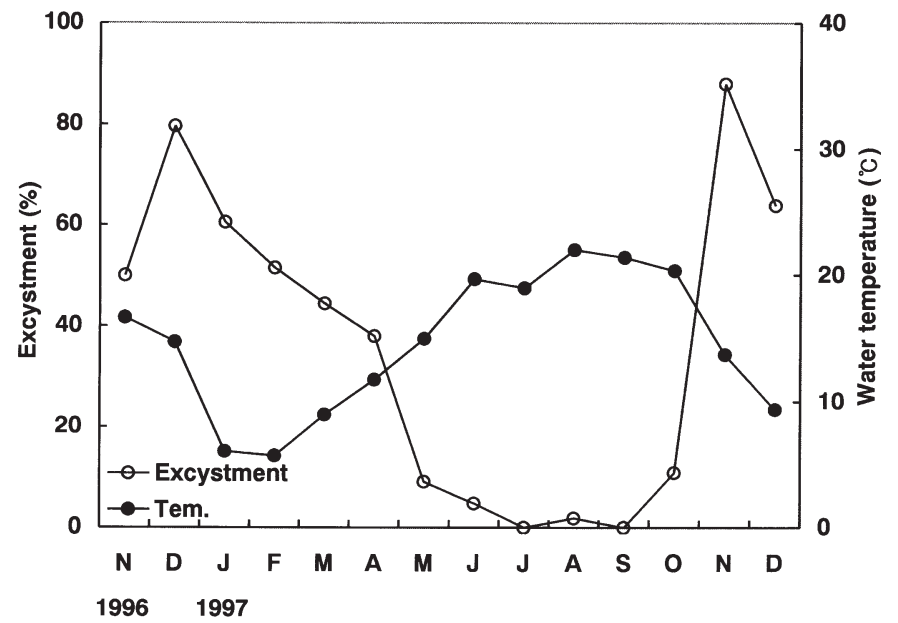

Fig. 6. Alexandrium tamarense. Seasonal changes in cumulative excystment $(\%)$ and bottom $(12 \mathrm{~m})$ temperature $\left({ }^{\circ} \mathrm{C}\right)$

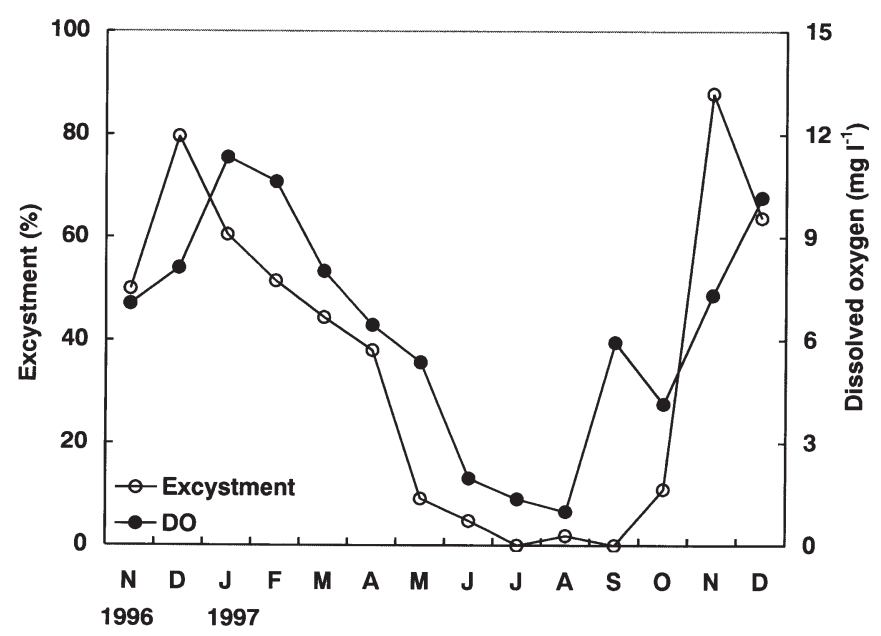

Fig. 7. Alexandrium tamarense. Seasonal changes in cumulative excystment $(\%)$ and bottom $(12 \mathrm{~m})$ dissolved oxygen $\left(\mathrm{mg} \mathrm{l}^{-1}\right)$

ever, in the present study with A. tamarense, germination success was very low during the summer period with lower salinity due to the summer monsoon (Fig. 8).

The scale of encystment and excystment largely affects cyst abundance in sediments. In general, it is recognized that sediment cyst concentrations of Alexandrium tamarense increase during or after blooms of vegetative cells in the water column and decrease prior to the bloom (Perez et. al. 1998). Similarly, there were significant decreases in cyst concentrations beginning in March, just at the time $A$. tamarense bloom begins. Mass encystment was observed in June when the spring bloom started to decline (unpubl. data). Newly formed cysts are ex-

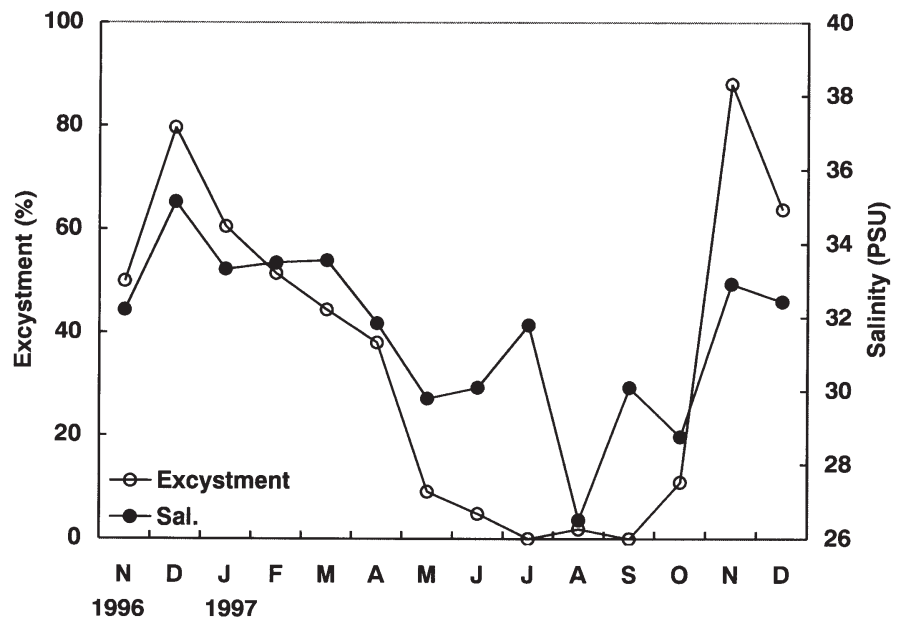

Fig. 8. Alexandrium tamarense. Seasonal changes in cumulative excystment (\%) and bottom (12 m) salinity (PSU)

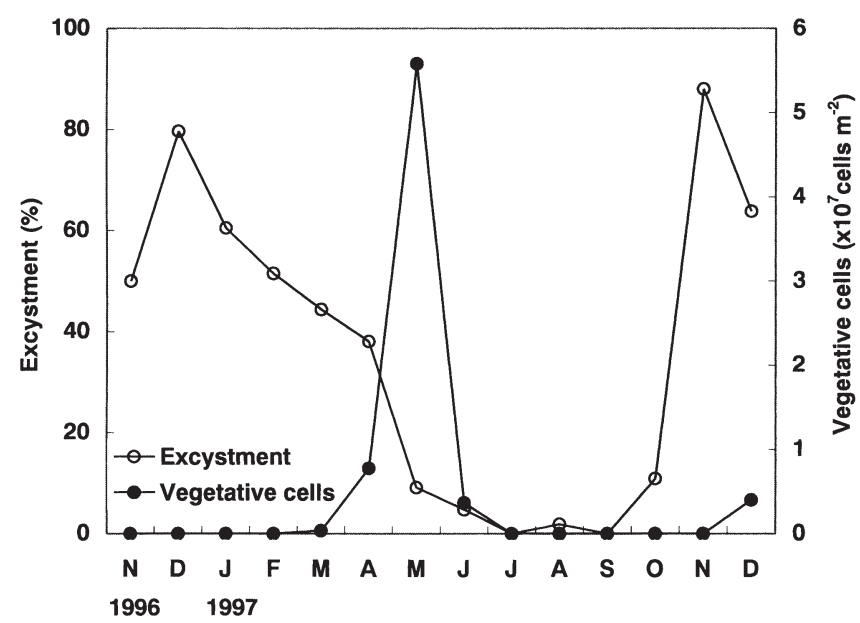

Fig. 9. Alexandrium tamarense. Seasonal changes in cumulative excystment $(\%)$ and vegetative cell numbers (cells $\mathrm{m}^{-2}$ )

pected to deposit on the sediments and lead to an increase of cyst abundance. Taking into consideration the sinking speed of $A$. tamarense cysts $\left(8.6 \mathrm{~m} \mathrm{~d}^{-1}\right.$; Anderson et al. 1985), new cysts in the water column settle rapidly on the sediments as detected in the increase of cyst abundance from July. Furthermore, cyst germination in the sediments was on a minor scale from July to September in summer. The increase of cyst abundance from July to September may reflect the eventual dominance of cyst deposition over cyst germination. Therefore, the number of cysts in the sediments seems to correlate reasonably well with bloom dynamics, both during initiation and decline.

The bimodal nature of Alexandrium blooms in this study is similar to the results from a Cape Cod salt 
pond (Anderson \& Morel 1979), i.e. a large bloom in the spring followed by a summer interval with no vegetative cells and a much smaller bloom in the fall. The dynamics of the bloom populations are the same in these 2 very distant regions. In the salt pond, the higher germination success recorded in spring and fall coincided with the vegetative population blooms. Lower germination success was observed during high temperature seasons in both regions. The spring bloom of Alexandrium tamarense in the salt pond was triggered by germination of the overwintering hypnozygotes concomitant with a gradual increase in temperature. Also in this study, the early spring excystment in March and April, which takes place at moderate water temperatures of 9 to $15^{\circ} \mathrm{C}$, might contribute to seeding the bloom. Although the germination success in early spring was not high, the excysted cells could proliferate in increasing temperatures.

A 5 mo interval between the germination and the bloom peak (Fig. 9) was in a lower temperature period $\left(<10^{\circ} \mathrm{C}\right)$. As the optimal temperature for growth of vegetative cells in north temperate waters is ca. $15^{\circ} \mathrm{C}$ (Ogata et al. 1987, Anderson \& Keafer 1987, Perez et. al. 1998), it is difficult to sustain the winter populations originated by massive fall germination. Predators of mesozooplankton also threaten population sustainability. Therefore, pre-winter germination is not effective as a seed for the spring bloom of Alexandrium tamarense. Similar germination results of A. tamarense were observed in Hiroshima Bay (Itakura \& Yamaguchi 2001). Interestingly, the temporal discrepancy between germination and blooming was also observed in another dinoflagellate, Scrippsiella trochoidea, from Yongil Bay on the southeastern coast of Korea (Kim \& Han 2000).

The vegetative population developed from the excysted cells in the fall was very difficult to detect in a countable biomass. We monitored the population dynamics of Alexandrium tamarense for $10 \mathrm{yr}$ in the same study area. The occurrence of vegetative population in the fall was seldom detected in the common sampling method using the Van Dorn sampler due to much smaller cell density in the water column. Further investigation should try to find an ecological meaning of the massive fall germination and the small fall population in regards to the survival advantages of A. tamarense.

Acknowledgements. We sincerely thank the anonymous reviewers for their constructive comments on this manuscript. This research was supported by the National Research Laboratory Program (2000-N-NL-01-C-290) of the Korean Ministry of Science \& Technology.

\section{LITERATURE CITED}

Anderson DM (1980) Effects of temperature conditioning on development and germination of Gonyaulax tamarensis (Dinophyceae) hypnozygotes. J Phycol 16:166-172

Anderson DM (1998) Physiology and bloom dynamics of toxic Alexandrium species, with emphasis on life cycle transitions. In: Anderson DM, Cembella AD, Hallegraeff GM (eds) Physiological ecology of harmful algal blooms. NATO ASI Series, Vol G 41. Springer-Verlag, Berlin, p 29-48

Anderson DM, Keafer BA (1987) An endogenous annual clock in the toxic marine dinoflagellate Gonyaulax tamarensis. Nature 325:616-617

Anderson DM, Morel FMM (1979) The seeding of two red tide blooms by the germination of benthic Gonyaulax tamarensis hypnocysts. Estuar Coast Mar Sci 8:279-293

Anderson DM, Wall D (1978) Potential importance of benthic cysts of Gonyaulax tamarensis and Gonyaulax excavata in initiating toxic dinoflagellate blooms. J Phycol 14:224-234

Anderson DM, Lively JJ, Reardon EM, Price CA (1985) Sinking characteristics of dinoflagellate cysts. Limnol Oceanogr 30:1000-1009

Anderson DM, Taylor CD, Armbrust EV (1987) The effects of darkness and anaerobiosis on dinoflagellate cyst germination. Limnol Oceanogr 32:340-351

Blomqvist P, Bell RT, Olofsson H, Stensdotter U, Vrede K (1995) Plankton and water chemistry in Lake Njupfatet before and after limiting. Can J Fish Aquat Sci 52:551-565

Cannon J (1993) Germination of the toxic dinoflagellates, Alexandrium minutum, from sediments in the Port River, South Australia. In: Smayda TJ, Shimizu Y (eds) Toxic phytoplankton blooms in the sea. Elsevier Science, Amsterdam, p 103-107

Hallegraeff GM, Marshall JA, Valentine J, Hardiman S (1998) Short cyst-dormancy period of an Australian isolate of the toxic dinoflagellate Alexandrium catenella. Mar Freshw Res 49:415-420

Han MS, Jeon JK, Kim YO (1992) Occurrence of dinoflagellate Alexandrium tamarense, a causative organism of paralytic shellfish poisoning in Chinhae Bay, Korea. J Plankton Res 14:1581-1592

Han MS, Jeon JK, Yoon YH (1993) Distribution and toxin profiles of Alexandrium tamarense (Lebour) Balech (Dinoflagellate) in the southeastern coastal waters, Korea. Korean J Phycol 8:7-13

Ishikawa A, Taniguchi A (1996) Contribution of benthic cysts to the population dynamics of Scrippsiella spp. (Dinophyceae) in Onagawa Bay, Northeast Japan. Mar Ecol Prog Ser 140:169-178

Ishikawa A, Taniguchi A (1997) In situ germination patterns of cysts, and bloom formation of some armored dinoflagellates in Onagawa Bay, north-east Japan. J Plankton Res 19:1783-1791

Itakura S, Yamaguchi M (2001) Germination characteristics of naturally occurring cysts of Alexandrium tamarense (Dinophyceae) in Hiroshima Bay, Inland Sea of Japan. Phycologia 40:263-267

Kim HG, Lee SG, Lim WA, Lee JS, Lim JH (1996) Environmental physiology of Alexandrium tamarense isolated from Chinhae Bay, the South Sea of Korea. In: Yasumoto T, Oshima Y, Fukuyo Y (eds) Harmful and toxic algal blooms. Intergovernmental Oceanographic Commission of UNESCO, Paris, p 57-60

Kim YO, Han MS (2000) Seasonal relationships between cyst germination and vegetative population of Scrippsiella trochoidea (Dinophyceae). Mar Ecol Prog Ser 204:111-118 
Méndez S, Severov D, Ferrari G, Mesones C (1996) Early spring Alexandrium tamarense toxic blooms in Uruguayan waters. In: Yasumoto T, Oshima Y, Fukuyo Y (eds) Harmful and toxic algal blooms. Intergovernmental Oceanographic Commission of UNESCO, Paris, p 113-116

Ogata T, Ishimaru T, Kodama M (1987) Effect of water temperature and light intensity on growth rate and toxicity change in Protogonyaulax tamarensis. Mar Biol 95:217-220

Park MH (1999) Population dynamics of Alexandrium tamarense cysts and vegetative cells in Masan Bay, Korea. MSc thesis, Hanyang University, Seoul (in Korean with English abstract)

Parsons TR, Maiat Y, Lalli CM (1984) A manual of chemical and biological methods for seawater analysis. Pergamon Press, New York, p 135-141

Perez CC, Roy S, Levasseur M, Anderson DM (1998) Control of germination of Alexandrium tamarense (Dinophyceae) cysts from the lower St. Lawrence estuary (Canada).

Editorial responsibility: David Caron,

Los Angeles, California, USA
J Phycol 34:242-249

Sekiguchi K, Inoguchi N, Kikuchi T, Kaga Y and 5 others (1996) Comparison of bloom patterns of Alexandrium tamarense between two bays in Iwate prefecture, northern Japan, in association with the toxicity of the scallop, Patinopecten yessoensis. In: Yasumoto $\mathrm{T}$, Oshima $\mathrm{Y}$, Fukuyo Y (eds) Harmful and toxic algal blooms. Intergovernmental Oceanographic Commission of UNESCO, Paris, p 223-226

Therriault JC, Painchaud J, Levasseur M (1985) Controlling the occurrence of Protogonyaulax tamarensis and shellfish toxicity in the St. Lawrence Estuary: freshwater runoff and the stability of the water column. In: Anderson DM, White AW, Baden DG (eds) Toxic dinoflagellates. Elsevier Science, New York, p 141-146

Turpin DH, Dobell PER, Taylor FJR (1978) Sexuality and cyst formation in pacific strains of the toxic dinoflagellate Gonyaulax tamarensis. J Phycol 14:235-238

Submitted: November 20, 2001; Accepted: July 18, 2002

Proofs received from author(s): September 6, 2002 